\title{
The Legal Analysis of Signature Forgestion Handling Process in Land Selling by PPAT
}

\author{
Siti Mutmainah ${ }^{*}$ and Hepy Hapsari ${ }^{* *}$ \\ ${ }^{*}$ Student of Master of Law, Universitas Islam Sultan Agung Semarang, E-mail: \\ mutmainahsiti169@gmail.com \\ ${ }^{* *}$ ) Student of Master of Notarial Law, Universitas Islam Sultan Agung \\ Semarang email : hepyhapsari21@gmail.com
}

\begin{abstract}
The problems in this research, first: how Legal Analysis of the Process of Handling Signature Falsification in the Sale and Purchase of Land Conducted by PPAT in Semarang City (Live Study Case No. 505/Pdt.G/2020/Pn.Smg)? Second, what is the legal consequence of the Minuta Akta which is falsified by a notary? This research is a normative study. The results of the study conclude, first: the implications for the notary position can be categorized into four (4) aspects, namely, i) implications for deed engagement, ii) aspects of administrative positions; iii), Professional Aspects of Membership; vi), the criminal aspect. Second, the legal consequence of the Minuta deed which is falsified by the notary is that the deed only has the power of proof as an underhand deed, if the parties can prove the untruth of the authentic deed in court proceedings and result in the deed being canceled and the power of proof as the deed below hands will no longer apply.

Keywords: Signature; Forgestion Handling; Land.
\end{abstract}

\section{Introduction}

Notary \& PPAT as General Officials have a central role in enforcing the law in Indonesia, because in addition to the large quantity of notary \& PPAT, notary \& PPAT are known as elite groups in Indonesia. Society still needs a writer as long as there is writing, especially to serve those who are not good at writing. The author in question will act as a witness for those who need it. The writing is clear and reliable and states what the requesting assistance was doing. This writing skill function is the basis of what is currently known as the Notariat. ${ }^{1}$

Notary is a respectable profession and is always related to morals and ethics when carrying out their duties. When carrying out their duties, notary and PPAT stick to and uphold the dignity of their profession as an honorable position. Because of the adherence of ethics to the notary profession, it is called a noble profession (Officium Nobile). ${ }^{2}$

The meaning of notary \& PPAT is in Article 1 paragraph 1 of Act No. 2 of 2014 concerning the Position of Notary which states "Notary is a public official who is authorized to make authentic deeds and has other powers as referred to in this law or based on other laws." ${ }^{3}$

\footnotetext{
${ }^{1}$ Soertardjo Soemoatmodjo, Apakah Notaris Pejabat Pembuat akta Tanah Pejabat lelang, Liberty, Yogyakarta.

${ }^{2}$ Abdul Ghofur Anshori, Lembaga Kenotariatan Indonesia,Perspektif Hukum dan Etika, UII Press, Yogyakarta, 2009, p. 6.

${ }^{3}$ See Article 1 paragraph 1 of Law of the Republic of Indonesia Number 2 of 2014 concerning Notary Position. 4 Abdul Ghofur Anshori, Op. Cit. p. 5.
} 
Notary and PPAT as free human beings and as an important element in nation building should be attached to the characteristics of humanism, given its significant role in social traffic, notary \& PPAT as state officials who are authorized to make deeds more or less affect the rights and obligations of the parties who facing him, legalization from a notary is very necessary to prove that there is an act and certain rights and obligations.

Notary are also obliged according to the notary code of ethics, namely service ethics to clients, as a notary public official can provide legal services to people who need their best services, complete deeds to the registration stage at district courts and announcements in state bonds, if the client concerned with expressly stated that he will hand over the management to the notary concerned and his client will meet the necessary requirements. ${ }^{4}$

In essence, authentic deeds contain the formal truth in accordance with what the parties have notarized to the notary. However, the Notary Public has an obligation to ensure that what is contained in the Notary Deed has truly been understood and is in accordance with the wishes of the parties, namely by reading it so that the contents of the Notary Deed are clear, as well as providing access to information regarding the relevant laws and regulations for the signatories to the deed. Thus, the parties can decide freely whether to agree or not to agree to the contents of the Notary Deed that will be signed. The signature on an authentic deed serves as a sign of approval of the obligations attached to the deed. ${ }^{5}$

Minuta deed can be said to be the life of a notary public, in that minuta contains the wishes of the parties or parties and at the end of the deed the signatures of the parties and the notary are written. Before the deed is signed, the Notary is obliged to read the contents of the deed so that the parties understand it. Even if it is not read out, the tappers must initial each of the deeds.

A copy of Deed is a word-for-word copy of all deeds and at the bottom of the deed is the phrase "given as a copy with the same sound." For clients who request that the deed be drawn up before a notary public, making a copy of the deed must be guided by the minimum amount of the deed. A copy of the deed is available after the minimum deed has been made by the Notary. The definition of a copy of the deed is clarified in Article 1 point 9 of the UUJN, which is a word-for-word copy of all deeds and at the bottom of the copy of the deed is the phrase "given as a copy with the same sound". In the copy of the deed, there is a notary statement starting from the beginning of the deed and the end of the deed. The beginning of the deed states that the parties have appeared to the notary public and at the end of the deed there is a statement that the minuta of the deed has been signed perfectly and the copy is the same. $^{6}$

Problems that arise exist in cases that have received decisions from Supreme Court of the Republic of Indonesia Number No. 505/Pdt.G/2020/PN.SMG who made Notary

\footnotetext{
${ }^{4}$ Sudikno Mertokusumo, Hukum Acara Perdata Indonesia, Liberty, Yogyakarta, 1998, p.149.

5 www.fairuzelsaid.wordpress.com/cyber-law-tanda-tangan-digital/ accessed on Saturday June, 17, 2016.

${ }^{6}$ Mulyoto, Agreement Perjanjian (Teknik, cara membuat, dan hukum perjanjian yang harus dikuasai), Cakrawala Media, Yogyakarta, 2011, p. 8.
} 
and PPAT Al Halim, SH, M.Kn., MH, Notary in Semarang City who were suspected and convicted of committing a criminal act, namely making a deed by falsifying the sign of the complainant, where the party suffering material loss due to the act, power of attorney to sell Number 03 Date 08-08-2018, Number 10 Date 30-10-2018, Number 03 Date 15-5-2019, and Number 25-09-2019 Based on the incident Notary and PPAT AI Halim, SH, M.Kn., MH, hope that they will be sued by the Public Prosecutor under Article 263 paragraph 1 and Article 264 paragraph 1 of the Criminal Code (hereinafter referred to as KUHP) on charges of making false letters/documents.

This study aims to, first, analyze the process of handling signature forgery in the sale and purchase of land carried out by PPAT in the city of Semarang (Live Study Case No. 505/Pdt.G/2020/Pn.Smg). Second, to determine the legal consequences of Minuta Deed falsified by Notary \& PPAT

\section{Research Methods}

This type of research is normative research, so that more than one research approach can be used. ${ }^{7}$ While the object of this research is "Legal Analysis of the Process of Handling Signature Falsification in the Sale and Purchase of Land Conducted by PPAT in the City of Semarang (Live Study Case No. 505/Pdt.G/2020/Pn.Smg)". While the collection of research materials is carried out by studying data that has a relationship with the problem, which is obtained from secondary data supported by primary data in the form of interviews with resource persons, secondary data is data obtained from library materials. ${ }^{8}$

\section{Results and Discussion}

\subsection{Legal Analysis of the Process of Handling Signature Counterfeiting in the Sale and Purchase of Land}

Chronology of Case Number 505/Pdt.G/2020/Pn.Smg, The case that occurred in Semarang, where the case between the defendant, namely Notary and PPAT Al Halim, $\mathrm{SH}, \mathrm{M} . \mathrm{Kn}$., MH, who had collaborated and was involved with PT. Inti Cahaya Property in falsifying the Sale and Purchase Power of Attorney with the Victim's Witness, namely Achmadi, the case was registered in the Semarang City District Court. In October 2017 there was a bargain for the sale and purchase price of land between Achmadi (land owner) and Developer (PT. Inti Cahaya Roperty) and agreed to a price of IDR 1,225,000 (One Million Two Hundred Twenty Five Thousand Rupiah) DP. As much as IDR 300,000,-(Three Hundred Million Rupiah) and ask for payment of the duration of 12 months, starting from February 2018, requesting 3 months for the distribution of land, starting from Waarmarking (December 2017) to the end of February 2018. So the one-year payment ends in March 2019. The land is made of housing called Denaya Village. That Thursday, December 7, 2017, the witness victim Achmadi had a land sale and purchase bond with the developer of PT. Inti Cahaya Property which was legalized at the Notary Office and PPAT Al Halim, S, H., M.Kn., MH, Freehold Certificate Number 05424/1.125m, number 2764/935m, number

\footnotetext{
${ }^{7}$ Johnny Ibrahim, Teori dan Metodologi Penelitian Normatif, Bayumedia Publising, Malang, 2012, p. 300.

${ }^{8}$ Soejono Soekanto, Penghantar Penelitian Hukum, UI-Press, Jakarta, 2009, p. 51.
} 
$00911 / 1.817 \mathrm{~m}$ of the 3 certificates broken into (Based on the recognition of the Developer according to the site plan, there are 31 certificates, but based on the copy of the power of attorney issued by NOTARIS-PPAT Al Halim to become 35 units of certificates, on behalf of Achmadi. 10 Date 30-10-2018, Number 03 Date 15-5-2019, and Number 25-09-2019, the fact that land payments that should have been paid in March 2019 were not paid, That there was further legalization in the Waarmarking on December 20, 2019 with the following points: The total value of the transactions that have not been paid is IDR 2,325,000,000.00 (Two Billion Three Hundred Twenty Five Million Rupiah) The first payment is IDR 325,000,000.00 (Three Hundred and twenty five million rupiah) will be paid on 28-02-2020 Second payment of IDR 800,000,000,(eight hundred million rupiah) will be paid by the SECOND PARTY to the FIRST PARTY by handing over 2 houses of 2 floors, each with type 64M with a period of five months. (5 months from December is the month of May receipt of the unit) The deficiency of IDR 1,200,000,000,-(one billion two hundred million rupiah) will be paid 1 year from January 2020 or no later than 31-01-2021. Director of PT. Inti Cahaya Properti) on Saturday, August 15, 2020, stated as follows: Able to resolve the underpayment of IDR 25,000,000 (twenty five million rupiah) on May 31, 2020 to the victim witness Achmadi. Able to hand over 2 building units in lots B12 and B 10 on July 30, 2020 with the condition of the building ready for habitation to the victim witness Achmadi. That the fact that the house is ready for habitation, which was contracted at Waarmarking on December 20, 2019 (ready in May 2020) and stated in the statement letter on May 15, 2020 (ready in July 2020), is the reality of Unreal. That there had been a meeting and discussion on 15 August 2020 but it was deadlocked. So that this case was registered at the Semarang District Court. As a comparison of the Judge's Decision with the Supreme Court Decision Number $1234 \mathrm{~K} / \mathrm{Pid} / 2012$, in the city of Yogyakarta, and Case Number 177/Pid.B/2019? PN.Smg

Judges in the decision of the Supreme Court Number $1234 \mathrm{~K} / \mathrm{PID} / 2012$ in the city of Yogyakarta, and Case Number 177/Pid.B/2019? PN.Smg believes he is guilty of committing the criminal act of "FORGIVING LETTERS WITH AUTHENTIC ASSETS", such as falsifying the signatures of the interlocutors. Based on this category, Notary are subject to 4 kinds of juridical implications for the position of Notary.

\subsection{Implications of Deed Engagement}

According to the author, the judge's conviction is in accordance with what is stipulated in Article 48 paragraph (1) of Act No 2 of 2012 concerning the Position of Notary Public, that the contents of the deed are prohibited from being changed by: 1 . Replaced; 2. Added; 3. Crossed out; 4.

Pasted; 5. Deleted; and/or 6. Written over.

Notary \& PPAT in this case can be considered to have participated in and committed a crime, because there is evidence of a mismatch between the signature in the deed and the original signature of one of the parties based on evidence of lab results, but in this case the judge does not see the issuance of the deed made by the Notary PPAT al Halim, SH, M.Kn., M.H, based entirely on information from the parties, is a type of deed of the parties (Deed of Partij), notary's criminal liability arising from the decision 
is not in accordance with Act No 30 of 2004 concerning Position Notary and Act No 2 of 2014 amendment to Act No 30 of 2004 concerning Notary Position.

Pursuant to Article 1 number 7 of Act No 30 Year regarding the Position of Notary Public, Notary Deed is an authentic deed made by or before a Notary, according to the form and procedure stipulated in the law. Notary deeds in this case can be divided into two types/categories of notarial deeds, namely:

- Deed made by notary public (Deed of Relaas or Deed of Official), namely deed made by notary that contains a description of an action taken by the notary on a situation that is seen or witnessed by the notary

- Deeds drawn up before a notary (Deed Partij), namely deeds drawn up before a notary contain a description of what is explained or told by the parties who have presented to the notary.

Based on the above, the notary \& PPAT deed is a deed made by a notary and PPAT is a means of proof, in making a deed, a notary \& PPAT must pay attention to these norms in addition to the code of ethics and other statutory provisions. then the authors see the Deed of sale and purchase Number 03 Date 08-08-2018, Number 10 Date 30-102018, Number 03 Date 15-5-2019, and Number 25-09-2019 are made based on all information and statements described by the tappers, so that the deed is a deed made based on the wishes of the tappers (Akta Partij), so that in making the deed a notary has no interest whatsoever in the content of the word made. Notary \& PPAT al Halim, $\mathrm{SH}, \mathrm{M} . \mathrm{Kn}$., $\mathrm{MH}$ made the deed based on the information and statements received, so that all contents and materials of the deed are the responsibility of the tappers, in Partij acte notary \& PPAT there is no need to prove the truth material from the statements of the parties.

According to Habib Adjie, ${ }^{9}$ material proof (material bewijskracht), is certainty about the material of a deed, that what is stated in the deed is valid evidence against the parties who made the deed or those who get rights and apply to the public, unless there is evidence to the contrary (Tegenbewijs). Statements that are contained/contained in official deeds (or minutes), or statements or parties given/conveyed before a notary (party deed) and the parties must be judged to be correct in speaking, which are then stated/contained in the deed must be deemed to have correctly said, if it turns out that the statements/statements of the parties are not true, so it is the responsibility of the parties themselves. Notary \& PPAT apart from that sort of thing. Thus the contents of the notary deed \& have certainty as the truth, become valid evidence for/among the parties and the heirs and their recipients of rights.

The judge must see that in reality the Deed made by Notary \& PPAT al Halim, SH, M.Kn., M.H., is only based on information, statements and was made at the will or request of his client, namely Achmadi. As a notary, in this case only make it in a form that has been determined according to law, and also a notary who is not a party to the deed, the inclusion of the notary's name \& PPAT in the deed because of a law order. There is no longer a legal relationship with the deed, because the deed can be canceled by proving that the deed is untrue and the power of evidence as an

\footnotetext{
9 Habib Adjie, Menilai Pembuktian Akta Otentik, http;//habibadjie.dosen narotama.ac.id/files/2013/07/Menilai-Pembuktin akta Notaris.pdf, accessed on 11 June 2016
} 
underhand deed is no longer valid and there has been a decision by the Supreme Court which has permanent legal force.

\subsection{Aspect of his Notary Administration Position}

In carrying out his duties, after he reads the deed, he should ask for the signature of the actor because in the absence of a signature of the tapper on the notary's deed it can cause the notary public to be, the possibility always exists, that a notary is facing a bad client or (in the case of a reconciliation) people cannot overcoming annoyance and the client can always state that he cannot write while in fact he is lying, the notary, if it is true the tapper cannot sign the deed, can take his fingerprints and the notary states the reason that the interperson cannot write or is unable to sign his/her signature Administrative sanctions can be in the form of written warning, temporary dismissal, honorific dismissal and dishonorable discharge.

\subsection{Professional aspects of membership}

According to the author, the legal implications that can arise from the decision of the Supreme Court Number 505/Pdt.G/2020/PN.SMG when viewed from a professional perspective on membership are as follows:

- Imposing criminal/sentencing to Notary Public \& PPAT will have an impact on reducing public trust in the notary position, which can cause legal uncertainty that affects the performance of a notary public.

- The sanctions shown against the notary are also an awareness that the notary and the PPAT in carrying out their duties have violated the provisions regarding the implementation of the duties of a notary as stated in the UUJN.

- The application of criminal sanctions in court decisions that have obtained legal force which in the ruling punishes the notary \& PPAT to undergo certain criminal processes as the verdict shows criminal liability against Notary who commit acts against the law as regulated in UUJN can be subject to criminal sanctions such as what is regulated in the criminal law (KUHP).

\subsection{Criminal Aspects}

In essence, sanctions are juridical instruments that are given when the obligations or prohibitions in legal provisions are violated. ${ }^{10}$ Disobedience or violation of an obligation contained in a legal rule that results in disorder that is not desired by the relevant legal rule.

However, the Notary \& PPAT may make a mistake in making the deed, Errors that may occur, namely: 1.Type error in the copy of the Notary, in this case the error can be corrected by making a new copy that is the same as the original and only the same copy with the original, the new has the same power as the original deed; 2 . Errors in the form of the notary deed \& PPAT, in this case where the minutes of the meeting should have been made but the notary made it as a statement of the meeting decision; 3. Errors in the contents of the notary deed \& PPAT, in this case regarding

\footnotetext{
${ }^{10}$ Tatiek Sri Djamiati, in Habib Adjie, Op.Cit. p. 90
} 
the statements of the parties before the Notary Public, where the deed was deemed correct but later turned out to be incorrect. ${ }^{11}$

If there is a disputed notary deed by the parties or those concerned, then to settle it must be based on the cancellation and cancellation of the Notary deed as a perfect evidence. Errors that occur in the deeds made by the Notary will be corrected by the judge when the Notary deed is submitted to the court as evidence.

In general, a deed is a signed letter, containing information about events or things that are the basis of an agreement. It can be said that the deed is a writing in which a legal act is stated. Some of these deeds are authentic and some are under hand.

The meaning of the word "to sign" (Ondertekenen) ethymologically (the science of our origins) is easy to find, that is to sign (sign) under something, but in practice the use of those words, the definition written above is unsatisfactory and in everyday use. It provides a more distinctive meaning, which the legislators may also mean cannot be explained by the word "signature".

According to Hermin Hediati Koeswadji, an act against the law in the context of a crime or an act which is prohibited by law and which is punishable by punishment has the following elements: a. Objective elements are elements that exist outside of humans, which can be in the form of: 1) An act or conduct which is prohibited and is threatened with criminal sanctions, such as falsifying documents, perjury, theft; 2) A certain result which is prohibited and which is threatened with criminal sanctions by law, such as murder, maltreatment; 3) Circumstances or things that are specifically prohibited and threatened with criminal sanctions by law, such as inciting, violating public morals. b. Subjective elements are the elements that are present in humans.

Thus, the punishment of notary and PPAT can be carried out with limitations if: 1) There is legal action from the notary against the formal aspects of the deed which is deliberate, full of awareness and conviction and is planned, that the deed made before a notary or by a notary jointly (agreed) to be used the basis for committing a criminal act; 2) There is a legal action from a notary in making deeds before or by a notary which if measured based on the Law on Notary Position is not in accordance with the Amendment Law on the UUJN and; 3) The action of the notary is not appropriate according to the agency authorized to judge a notary's act, this is stated in the Notary Supervisory Council. ${ }^{12}$

The occurrence of convictions against Notary \& PPAT based on deeds made by or before the Notary as part of the implementation of the duties of the office or notary's authority, without paying attention to the legal rules relating to the procedures for making deeds and only based on the provisions of the Criminal Code (KUHP) only, shows there has been a misunderstanding or interpretation of the notary's position while the authentic deed made by the Notary is as evidence in Civil Law. Criminal

\footnotetext{
${ }^{11}$ Mudofr Hadi, Varia Judicial Year VI Number 72, Pembatalan Isi Akta Notaris Dengan Putusan Hakim, 1991, p. 142-143.

12 Habib Adjie, 2005, Limitation on the Criminalization of Notary, Renvoi Journal, Number 10-22 Dated March 3, p. 123125.
} 
sanctions are ultimum remedium, namely the last remedy, if the sanctions or attempts at other branches of law are incapable or deemed ineffective. ${ }^{13}$

A notary is required to always take a careful attitude or be careful in addressing every case in his/her job duties, considering that a notary has professional abilities both theoretically and practically.

Based on an interview with a notary public \& PPAT, DR. Ngadino, SH, Sp.N., MH, as a notary in the city of Semarang, that changes to the UUJN so that Notary can avoid violations/legal actions, it is necessary for Notary to be smart about reading the situation with anticipation by making a statement, that the facing right is the real tappers and during the signing process two witnesses must be witnessed. ${ }^{14}$ In practice, it is found that a legal action committed by a notary can actually qualify as a criminal act committed by a notary public. The aspect that is used as a limitation in the case of notary violations must be measured based on the Amendment Law on UUJN, meaning whether the actions of the Notary violate certain articles in the Amendment Law of UUJN that the deed is in accordance with the Amendment Law on UUJN, but if according to the investigator the act is a criminal act. Thus, before conducting further investigations, it is advisable to ask for the opinion of an expert who knows with certainty about this matter, namely from the notary office organization. The threat of such sanctions is intended so that in carrying out their duties and positions,

\subsection{Legal Consequences against Minuta Deeds Falsified by Notary.}

One of the legal terms of the agreement contained in Article 1320 of the Civil Code which contains the agreement of the parties, the ability to act, the existence of certain things that have been agreed upon and the existence of a lawful cause for the agreement. If a deed gives rise to a criminal offense, the terms of the agreement are considered to be the elements of the agreement contained therein. Legal experts such as Sudikno Mertokusuno, Mariam Darus, and J. J. Satrio agreed that the elements of the agreement consisted of essential elements, natural elements, and accidental elements. $^{15}$

The first element is commonly called the core part of the agreement, the second and third elements are called the non-core part of the agreement. Essential elements are elements that absolutely must be there for the agreement to occur, so that the agreement is valid and this is a condition of the validity of the agreement. So the four conditions in Article 1320 of the Civil Code are the essential elements of the agreement. In other words, the essential nature of the agreement is the nature that determines the agreement created (constructieve oordeel).

The naturalia element is an element that is commonly attached to an agreement, namely an element that is not specifically agreed upon in a tacit agreement automatically considered to be in the agreement. This element is inherent (natuur) or

\footnotetext{
${ }^{13}$ Habib Adjie, 2005, "Limitation of Notary Criminalization", Renvoi Journal, Number 10-22 Dated March 3, p. 126.

${ }^{14}$ Interview Results during Pre-Internship at the Notary Office of Ety Ermawati as a Notary in Yogyakarta, on 10 May 2016.

15 Kartini Muljadi and Gunawan Widjaja, Perikatan yang Lahir dari Perjanjian, (Jakarta: Raja Grafindo Persada, 2010), p. 84.
} 
attached to the agreement. For example the seller must guarantee hidden defects to the buyer. While accidental elements, meaning elements that must be contained or expressly stated in the agreement by the parties. For example, in the event of a dispute, the parties have determined the chosen place. To prove a deed is valid or invalid in this research, the presumption of validity is used. The principle of presumption is valid (VermoedenVanRechtmatigheid) or Presumptio lustae Causa is a principle that considers a legal product valid before a court decision has permanent legal force which declares it invalid. With this principle, the authentic deed made by the Notary must be considered valid and binding on the parties before it can be proven that the authentic deed is invalid from the external, formal and material aspects.

In the provisions referred to in Article 41 UUJN-P which states if the Notary violates the provisions as referred to in Article 38, Article 39, and Article 40 UUJN-P results in the deed only having evidentiary power as an underhand deed, then the Notary deed only has the power of proof as an underhand deed, however, if the parties can prove the untruth of the authentic deed in court proceedings and it results in the deed being canceled and the power of proof as an underhand deed will no longer be valid. Because the principle of legal presumption is related to deeds that can be revoked, it is an act that contains a flaw, namely not having the authority of the Notary to make the deed physically, formally, materially and not in accordance with the legal rules regarding the making of Notary deeds.

The legal consequence of an authentic deed made by a notary against the law which causes the authentic deed to become a deed under the hands and the deed can be canceled is in line with the theory of authority and the concept of legal protection. As stated in the theory of authority, Notary in making authentic deeds are included in the authority by attribution, based on the provisions of Article 15 paragraph (1) of the Amendment Law on UUJN. The occurrence of a legal consequence, namely in the form of an authentic deed becomes an underhand deed and the deed is canceled due to an abuse of authority committed by a notary.

\section{Closing}

Legal analysis of the position of notary public \& PPAT can be categorized into four (4) aspects, namely, first, deed engagement, second aspect of administrative position; Third, the professional aspect of membership; Fourth, the criminal aspect; Second, the legal consequence of the Minuta deed which is falsified by the Notary \& PPAT is that the deed only has the power of proof as an underhand deed, if the parties can prove the untruth of the authentic deed in court and result in the deed being canceled as well as the power of proof as the deed below. Because the principle of legal presumption is related to deeds that can be canceled, it is an act that contains a flaw, namely not having the authority of the Notary to make the deed physically, formal, material and not in accordance with the legal rules regarding the making of Notary deeds. 


\section{References}

\section{Journals and the Internet}

[1] www.fairuzelsaid.wordpress.com/cyber-law-sign-hand-digital/_accessed on Saturday 17 June, 2016.

[2] Habib Adjie, Assessing Proof of Authentic Deed, http; // habibadjie.dosen narotama.ac.id/files/2013/07/Assessing-Proof of Notary deed.pdf, accessed on 11 June 2016

[3] Habib Adjie, 2005, Limitation of Notary Criminalization, Renvoi Journal, Number 10-22 Dated March 3

[4] Habib Adjie, 2005, "Limitation of Notary Criminalization", Renvoi Journal, Number 10-22 Dated March 3

\section{Book}

[1] Soertardjo Soemoatmodjo, Apakah Notaris Pejabat Pembuat akta Tanah Pejabat lelang, Liberty, Yogyakarta,

[2] Abdul Ghofur Anshori, Lembaga Kenotariatan Indonesia, Perspektif Hukum dan Etika, UII Press, Yogyakarta, 2009

[3] Sudikno Mertokusumo, Hukum Acara Perdata Indonesia, Liberty, Yogyakarta, 1998,

[4] Mulyoto, Perjanjian (Teknik, cara membuat, dan hukum perjanjian yang harus dikuasai), Cakrawala Media, Yogyakarta, 2011

[5] Johnny Ibrahim, Teori dan Metodologi Penelitian Normatif, Bayumedia Publising, Malang, 2012, p. 300.

[6] Soejono Soekanto, Penghantar Penelitian Hukum, UI-Press, Jakarta, 2009

[7] Mudofr Hadi, Varia Judicial Year VI Number 72, Pembatalan Isi Akta Notaris Dengan Putusan Hakim, 1991.

[8] Kartini Muljadi and Gunawan Widjaja, Perikatan yang Lahir dari Perjanjian, (Jakarta: Raja Grafindo Persada, 2010)

\section{Regulation}

[1] Civil Code

[2] Criminal Code

[3] Supreme Court Decision Number 1234/K/PID/2012.

[4] Act No 2 of 2014 concerning Amendments to Act No 30 of 2004 concerning Law on Notary Position. 